PYTHAGORAS: Jurnal Pendidikan Matematika

Volume 10 - Nomor 2, Desember 2015, (146-154)

Available online at: http://journal.uny.ac.id/index.php/pythagoras

\title{
Keefektifan Pendekatan Realistik Ditinjau dari Prestasi Belajar, Kemampuan Pemecahan Masalah, dan Kepercayaan Diri Matematika
}

\author{
Hanna Filen Sopia ${ }^{1)}$, Dhoriva Urwatul Wutsqa ${ }^{2)}$ \\ ${ }^{1}$ Program Studi Pendidikan Matematika, Program Pascasarjana, Universitas Negeri Yogyakarta. Jalan \\ Colombo No. 1, Karangmalang, Yogyakarta 55281, Indonesia. Email: hannafilensopia@ gmail.com \\ ${ }^{2}$ Pendidikan Matematika, Universitas Negeri Yogyakarta, Jl. Colombo No. 1, Karangmalang, \\ Yogyakarta 55281, Indonesia. Email: dhoriva@yahoo.com
}

\begin{abstract}
Abstrak
Penelitian ini bertujuan untuk mendeskripsikan: keefektifan pembelajaran matematika dengan pendekatan realistik; dan pembelajaran yang lebih efektif antara pendekatan realistik dengan pembelajaran konvensional ditinjau dari prestasi belajar, kemampuan pemecahan masalah, dan kepercayaan diri matematika siswa. Penelitian ini merupakan penelitian eksperimen semu dengan desain kelompok kontrol pretest-posttest beracak. Penelitian ini menggunakan satu kelompok eksperimen dan satu kelompok kontrol. Populasi penelitian ini adalah seluruh siswa kelas VIII SMP Negeri 3 Pandeglang. Sampel penelitian sebanyak dua kelas yang dipilih secara acak. Data hasil penelitian dianalisis dengan MANOVA, dan untuk mengetahui keefektifan pendekatan realistik menggunakan uji one sample t-test. Hasil penelitian ini menunjukkan bahwa: pendekatan realistik efektif terhadap pembelajaran matematika ditinjau dari prestasi belajar dan kepercayaan diri matematika siswa namun tidak efektif ditinjau dari kemampuan pemecahan masalah; pendekatan realistik lebih efektif dari pembelajaran konvensional ditinjau dari prestai belajar, kemampuan pemecahan masalah, dan kepercayaan diri matematika siswa.
\end{abstract}

Kata kunci: pendekatan realistik, prestasi belajar, kemampuan pemecahan masalah, kepercayaan diri.

\section{The Effectiveness of Realistic Approach Based on Learning Achievement, Problem Solving Ability, and Mathematical Self Confidence}

\begin{abstract}
This study aims to describe: the effectiveness of teaching mathematics using realistic approach; and the more effective teaching between realistic approach and conventional teaching based on studens' learning achievement, problem solving ability, and mathematical self-confidence. This research was a quasi experimental study employing a random pretestt-posttest control group design. It involved one experimental group and one control group. The research population comprised nine classes of Year VIII student of SMP Negeri 3 Pandeglang. The sample consisted of two classes that were randomly established. The data were analysed by means of MANOVA, and to test the effectiveness of realistic approach using one sample t-test. The result of the study show that: realistic approach is effective in learning mathematics based on learning achievement and mathematical self confidence of student but not effective based on problem solving ability; realistic approach more effective than conventional learning based on learning achievement, problem solving ability and mathematical self confidence of student.
\end{abstract}

Keywords: realistic approach, learning achievement, problem solving ability, self-confidence.

How to Cite Item: Sopia, H., \& Wutsqa, D. (2015). Keefektifan pendekatan realistik ditinjau dari prestasi belajar, kemampuan pemecahan masalah, dan kepercayaan diri matematika. PYTHAGORAS: Jurnal Pendidikan Matematika, 10(2), 146-154. Retrieved fromhttp://journal.uny.ac.id/index.php/pythagoras/article/view/9139 


\section{PENDAHULUAN}

Matematika sekolah adalah matematika yang diajarkan pada jenjang pendidikan dasar dan jenjang pendidikan menengah yang bertujuan untuk menumbuhkembangkan kemampuan-kemampuan dan membentuk pribadi siswa melalui matematika (Suherman, 2003, pp.5556). Tujuan umum yang dirumuskan oleh matematika sekolah senada dengan yang tujuan umum yang dirumuskan oleh National Council of Teachers of Mathematics NCTM (1989, p.5) yaitu pembelajaran matematika diajarkan agar siswa: (1) belajar menghargai matematika; (2) percaya diri dalam kemampuannya mengerjakan matematika; (3) menjadi problem solver matematika; (4) belajar untuk berkomunikasi secara matemati; (5) belajar untuk melakukan penalaran secara matematik. Berdasarkan hal tersebut terlihat bahwa tujuan dilaksanakannya pembelajaran matematika tidak hanya ingin menumbuhkembangkan kemampuan matematis siswa namun juga turut mengembangkan aspek afektif melalui pembelajaran matematika.

Namun pada kenyataannya di sekolah, tujuan umum yang telah dirumuskan tersebut tidak sesuai dengan pelaksanaannya pada proses pembelajaran di kelas. Banyaknya tuntutan ketercapaian kompetensi dalam kurikulum dan tuntutan keberhasilan dalam ujian yang lebih menekankan pada tujuan jangka pendek (Wijaya, 2012, p.17). Hal ini membuat pelaksanaan pembelajaran di kelas hanya berfokus pada bagaimana siswa mengingat rumus-rumus dan cara mengerjakannya sehingga siswa mudah lupa dengan apa yang telah mereka pelajari. Hal ini sesuai dengan pendapat Noyes $(2007$, p.11) bahwa banyak anak cenderung dilatih untuk melakukan perhitungan matematika daripada dididik untuk berpikir matematis.

Masalah lain yang terjadi di sekolah adalah proses pembelajaran matematika yang masih bersifat mekanistik. Situasi ini dimulai dengan guru menerangkan algoritma disertai contoh, kemudian siswa mengerjakan latihan sesuai contoh yang diberikan guru. Cara seperti ini lebih memfokuskan siswa mengingat cara-cara yang mereka ajarkan dalam memecahkan soal daripada menstimulasi mereka untuk mengkonstruksi pengetahuan (Fauzan \& Yerizon, 2013, p.8). Berbagai permasalahan tersebut ternyata membawa dampak pada prestasi belajar matematika siswa, kemampuan pemecahan masalah, dan kurang optimalnya kepercayaan diri siswa terhadap matematika.
Hal ini dapat dilihat dari hasil UN matematika siswa sekolah menengah pertama di daerah tempat penelitian yaitu Pandeglang dapat dilihat melalui hasil UN yang masih relatif rendah yaitu rata-ratanya sebesar 4,71 rata-rata ini masih relatif kecil dibandingkan dengan kabupaten atau kota lainnya yang ada di provinsi Banten. Selain itu rata-rata hasil UN matematika di SMP Negeri 3 Pandeglang menempati klasifikasi E dengan rata-rata sebesar 3,74 pada Tahun Ajaran 2012/2013. Hasil UN tersebut mengalami penurunan dari tahun sebelumnya yang menduduki klasifikasi $\mathrm{C}$ dengan rata-rata sebesar 6,26.

Beragam upaya telah dilakukan oleh sekolah-sekolah yang ada di Kabupaten Pandeglang termasuk SMPN 3 Pandeglang untuk meningkatkan hasil UN siswa melalui pelajaran tambahan dan memberikan rumusrumus cepat untuk mengerjakan soal UN. Namun karena bimbingan yang diberikan hanya menekankan pada kemampuan prosedural melalui hafalan rumus-rumus dan penyelesaiannya dalam mengerjakan soal, maka hal ini menjadi tidak bermakna karena pengetahuan yang diperoleh siswa tidak bertahan lama sehingga hasil yang didapatpun tidak sesuai dengan harapan. Hal ini menurut Freudenthal (1973, p.20) terjadi dikarenakan matematika yang diajarkan tersebut hanya sebagai produk yang siap pakai (ready made) sehingga menjadikan matematika kurang fleksibel dalam memberikan kesempatan kepada siswa untuk menemukan permasalahan.

Selain prestasi dan kemampuan pemecahan masalah, terdapat aspek afektif yang turut memberikan kontribusi terhadap keberhasilan siswa dalam belajar matematika. aspek afektif tersebut adalah kepercayaan diri. Dengan adanya rasa percaya diri, siswa memiliki kemampuan untuk mengambil tindakan yang tepat dan efektif dalam berbagai situasi, sekalipun muncul tantangan baik dari diri sendiri maupun dari orang lain (Burton, 2006, p.10). Rasa percaya diri pada siswa juga berguna untuk menciptakan suasana belajar yang mendukung siswa melaksanakan aktivitas pembelajaran dengan sebaikbaiknya, jujur dalam mengerjakan tugas dan percaya terhadap hasil jerih payah sendiri tanpa harus mencontek dengan orang lain.

Adapun hasil studi pendahuluan penulis yang dilakukan pada salah satu sampel kelas VIII di SMP Negeri 3 Pandeglang menunjukkan bahwa kepercayaan diri siswa terhadap matematika belum ada yang mencapai kriteria sangat 
tinggi. Sebagian besar siswa memiliki kepercayaan diri dengan kriteria sedang dan tinggi. Hal ini terjadi dikarenakan pembelajaran matematika yang tidak melibatkan siswa secara langsung dalam hal bertanya, berdiskusi, dan berpendapat untuk mengemukakan hasil yang telah diperolehnya selama proses pembelajaran membuat siswa tidak berani unjuk gigi untuk mengemukakan pendapatnya di depan kelas. Oleh karena itu masih diperlukan adanya suatu upaya untuk mengoptimalkan kepercayaan diri siswa terhadap matematika.

Upaya untuk membantu siswa dalam mengoptimalkan prestasi belajarnya, mengarahkan siswa untuk memiliki kemampuan pemecahan masalah yang baik. Prestasi belajar merupakan suatu pencapaian pengetahuan, keterampilan atau kompetensi siswa yang dikembangkan melalui pembelajaran di sekolah untuk mencapai tujuan pembelajaran (Phye, 1997, p.4; Collins \& O'Brien, 2003, p.4; McCoach, Gable, \& Madura, 2013, p.19; Nitko \& Brookhart, 2011, p.497). Sedangkan kemampuan pemecahan masalah merupakan kemampuan atau keterampilan siswa dalam menyelesaikan masalah kompleks dengan menerapkan konsep dan beragam kreativitasnya dalam mengerjakan non rutin, soal terbuka dan soal yang berkaitan dengan dunia nyata (Adam \& Hamm, 210' p.59; Bell, 1978, p.310; Karatas \& Baki, 2013, p.249; NCTM, 2000, p.52; Nitko \& Brookhart, 2011, p.231). Kemampuan siswa tersebut mencakup merumuskan masalah, mempertimbangkan strategi dalam menyelesaikan masalah, menerapkan beragam strategi dalam penyelesaian masalah, serta dapat memverifikasi dan menggeneralisasikan hasil yang diperoleh (Polya, 1957, p.xvi).

Sementara itu, kepercayaan diri yang dijadikan sebagai indikator diantaranya adalah percaya atau yakin pada kemampuan dirinya, mampu untuk mengambil tindakan yang efektif dan tepat, perasaan mengenai harga diri, percaya bahwa usahanya dapat mencapai tujuan, dan percaya pada kemampuannya untuk menyelesaikan masalah (Azmandian, 2010, p.79; Burton \& Platts, 2006, p.10; Goel \& Aggarwal, 2012, p.89; McElmeel, 2002, 27; Preston, 2001, p.18; Schunk, 2012, p.498; Srivastava, 2013, p.42; Yoder \& Proctor, 1988, p.4). Apabila prestasi belajar siswa mengalami peningkatan, hal ini akan berdampak positif pula pada kepercayaan diri siswa. Pernyataan ini dikuatkan dengan adanya penelitian yang dilakukan oleh Srivastava (2013, p.49) yang menunjukkan bahwa terdapat hubungan yang signifikan antara prestasi akade- mik dan level kepercayaan diri siswa, sebagai contoh siswa dengan prestasi akademik yang tinggi menunjukkan level kepercayaan diri yang tinggi pula dibandingkan dengan siswa yang memiliki level prestasi akademik yang rendah.

Solusi pada pembelajaran matematika yang dapat dilakukan untuk mengoptimalkan prestasi belajar, kemampuan pemecahan masalah, dan kepercayaan diri siswa terhadap matematika adalah dengan menerapkan suatu cara yang memperhatikan kontribusi siswa baik berupa ide ataupun gagasan sehingga diberikan kesempatan untuk lebih kreatif dalam mengkonstruksi jawaban. Siswa juga dapat saling berinteraksi antar sesama siswa, guru, maupun lingkungan belajarnya. Keterlibatan siswa dalam pembelajaran yang mencakup mengemukakan pendapat, bernegosiasi serta berdiskusi dalam pembelajaran, akan menjalin suatu komunikasi yang baik anara siswa dengan siswa maupun siswa dengan guru. Melalui proses ini, karakter siswa juga dapat terbentuk mulai dari rasa saling menghormati, sikap saling menghargai pendapat masing-masing, disiplin, serta keterlibatan siswa dalam menyampaikan ide dan gagasannya melalui strategi penyelesaian masalah yang dikemukakannya di depan kelas membuat siswa perlahan-lahan terbentuk rasa percaya dirinya ketika belajar matematika. Selain itu, siswa juga dapat menghubungkan dunia matematika dengan situasi kehidupan sehari-hari mereka sehingga pembelajaran yang dilakukan dapat menjembatani pengetahuan matematika siswa dengan dunia nyata yang dapat dibayangkan oleh siswa.

Praktik pembelajaran yang sesuai dengan hal tersebut adalah dengan menerapkan pendekatan pembelajaran yang dikenal dengan sebutan pendekatan realistik. Pendekatan ini menjadikan dunia nyata yang dapat dibayangkan oleh siswa sebagai titik awal pembelajaran (Van den Heuveul Panhuizen, 2001, 3). Selain itu terdapat lima karakteristik dalam pendekatan realistik yang dapat membantu untuk memperbaiki kualitas pembelajaran matematika di sekolah, yaitu fenomena didaktik yang dapat dibayangkan oleh siswa, menggunakan model yang dapat menjembatani matematisasi horizontal dan vertikal, menggunakan kontribusi siswa (student contribution), interaktivitas, dan keterkaitan antar topik (intertwinning) (Gravemeijer, 1994, pp.114115; Streefland, 1991, p.21).

Proses matematisasi horizontal tersebut akan memberikan akses untuk menuju ke arah yang lebih formal yang dimulai dari dunia nyata 
ke dunia simbol. Pada tahap tersebut siswa mencoba memanipulasi dan menyelesaikan soalsoal dengan melakukan prosedur matematika secara formal, dan ketika siswa sudah memasuki tahap tersebut berarti ini merupakan proses matematisasi vertikal (Freudenthal, 2002, pp.4142. Proses matematisasi yang dimaksud pada pendekatan realistik adalah proses yang melibatkan merumuskan masalah dan menafsirkan. Merumuskan masalah sebagai masalah matematika mencakup membuat struktur, konsep, asumsi, atau membangun model. Sedangkan interpretasi mencakup apakah dan bagaimana menentukan hasil dari soal atau tugas-tugas matematika yang berhubungan dengan masalah asli (original problem) dan menentukan pula cara yang tepat untuk mengerjakannya atau menyelesaikannya (OECD, 2014, 39). Proses matematisasi tersebut dapat membantu siswa untuk meningkatkan kemampuan pemecahan masalahnya dalam matematika.

Dengan demikian melalui pembelajaran dengan pendekatan matematika realistik ini diharapkan Kemampuan Pemecahan Masalah Matematika (KPMM), dan Kepercayaan Diri (KD) siswa dapat dikembangkan secara optimal sehingga berdampak positif pula pada Prestasi Belajar (PB) matematika siswa di kelas. Pendekatan realistik ini dapat pula dijadikan sebagai salah satu alternatif untuk menjadikan pembelajaran matematika menjadi lebih efektif, karena salah satu karakteristik yang ada pada pendekatan realistik yaitu interaktivitas dan penggunaan suatu konteks yang disesuaikan dengan lingkungan belajar siswa, terdapat pula pada karakteristik pembelajaran matematika yang efektif menurut Cai, et al (2009, pp.308-310) yaitu meliputi siswa terlibat aktif dalam pembelajaran, adanya aktifitas antar siswa di kelas, menghubungkan pembelajaran dengan kehidupan sehari-hari siswa dan menggunakan tipe mengajar yang cocok bagi siswa dan lingkungan belajarnya.

Berdasarkan beberapa penjelasan tersebut terlihat bahwa pendekatan realistik dapat dijadikan sebagai salah satu upaya untuk menjadikan pembelajaran di kelas lebih efektif dan mencapai tujuan pembelajaran. Sehingga pada penelitian ini peneliti bertujuan untuk mendeskripsikan keefektifan pembelajaran matematika dengan pendekatan realistik ditinjau dari prestasi belajar, kemampuan pemecahan masalah, dan kepercayaan diri siswa terhadap matematika. Selain itu untuk mendeskripsikan mana yang lebih efektif antara pembelajaran matematika yang menggunakan pendekatan realistik dengan pembelajaran konvensional ditinjau dari prestasi belajar, kemampuan pemecahan masalah, dan kepercayaan diri siswa terhadap matematika.

Selain bertujuan untuk mendeskripsikan beberapa hal yang terlah disebutkan sebelumnya, penelitian ini juga memiliki beberapa manfaat praktis yang dapat diambil dari penelitian ini, diantaranya adalah siswa memperoleh pengalaman belajar matematika dengan suatu pendekatan realistik, siswa memperoleh fasilitas belajar berupa LKS yang mengacu pada pendekatan realistik, dapat dijadikan alternatif pembelajaran oleh guru guna meningkatkan pembelajaran matematika di kelas khususnya dalam mengoptimalkan prestasi belajar, kemampuan pemecahan masalah, dan kepercayaan diri siswa terhadap matematika.

\section{METODE}

Subjek penelitian ini adalah siswa kelas VIII A dan VIII B SMP Negeri 3 Pandeglang Tahun Ajaran 2014/2015 yang terdiri atas 36 siswa dan 37 siswa. Penelitian ini merupakan eksperimen semu dengan desain penelitian pretest-posttest nonequivalen control group design. Pada desain ini terdapat dua kelompok yaitu kelompok eksperimen yang menerapkan pendekaran realistik dan kelompok kontrol yang menerapkan pembelajaran konvensional. Adapun teknik pengumpulan data yang digunakan dalam penelitian ini adalah mengumpulkan data sebelum diberikan perlakuan yaitu dengan memberikan pretest prestasi belajar, kemampuan pemecahan masalah, dan angket kepercayaan diri siswa terhadap matematika; melakukan tindakan penelitian dengan memberikan perlakuan pendekatan realistik pada kelas eksperimen; dan mengumpulkan data setelah diberikan perlakuan pada kelas eksperimen dan kontrol dengan memberikan posttest prestasi belajar, kemampuan pemecahan masalah, dan kepercayaan diri siswa terhadap matematika. Berikut merupakan reliabilitas dari ketiga instrumen tersebut.

Tabel 1. Nilai Alpha Cronbach

\begin{tabular}{cc}
\hline Intrumen & Nilai $\boldsymbol{\alpha}$ \\
\hline Prestai Belajar & 0,71 \\
Kemampuan Pemecahan Masalah & 0,70 \\
Kepercayaan diri & 0,78 \\
\hline
\end{tabular}

Teknik analisis data yang digunakan dalam penelitian ini adalah analisis deskriptif dan inferensial. Analisis deskriptif untuk mendeskripsikan keadaan sebelum dan sesudah diberikan perlakuan pada kedua kelas ditinjau dari 
masing-masing variabel terikatnya. Analisis inferensial dilakukan untuk mengambil kesimpulan berdasarkan data yang telah diperoleh selama proses penelitian berlangsung. Analisis inferensial ini terdiri atas uji keefektifan dan uji komparasi pembelajaran matematika.

Sebelum dilakuan analisis keefektifan perlu diketahui bahwa keefektifan pembelajaran matematika dapat ditentukan berdasarkan kriteria pencapaian tujuan pembelajaran yang ditunjukkan dengan ketuntasan belajar siswa dalam belajar matematika. Siswa dikatakan tuntas belajar ketika rata-rata kelas melebihi KKM 65 untuk Prestasi Belajar (PB). Sedangkan untuk Kemampuan Pemecahan Masalah Matematika (KPMM) skor maksimalnya adalah 50 sehingga siswa dikatakan tuntas apabila ratarata skor siswa melebihi skor 33 untuk KPMM. Sementara itu suatu pendekatan pembelajaran dikatakan efektif ditinjau dari Kepercayaan Diri (KD) matematika siswa ketika KD siswa dalam pembelajaran matematika masuk pada kategori tinggi yaitu skor yang diperoleh lebih dari 87 .

Data-data yang diperoleh selama penelitian berlangsung harus memenuhi uji asumsi terlebih dahulu sebelum melalui proses analisis. Uji asumsi yang harus dipenuhi adalah uji normalitas dengan menggunakan kriteria Chi square $x^{2}$ (Johnson \& Wichern, 2007, pp.182-183) yaitu nilai $d_{i}{ }^{2}<X^{2}{ }_{p}(0,5)$ mendekati $50 \%$ maka dapat dikatakan bahwa data tersebut berdistribusi normal multivariat. Selain itu, homogenitas kedua kelompok di uji dengan menggunakan uji Box-M (Huberty \& Olejnik, 2006, p.41). Jika nilai signifikansi yang diperoleh lebih dari 0,05 , maka matriks kovarians kedua populasi tersebut homogen.

Setelah melewati proses uji asumsi, maka dilanjut dengan One sample t-test untuk menganalisis keefektifan dari pendekatan realistik ditinjau dari masing-masing variabel terikatnya. Sementara itu, analisis perbedaan keefektifan antara pendekatan realistik dengan pembelajaran konvensional dilakukan dengan uji Multivariate Analysis of Variance (MANOVA) $T^{2}$ Hotelling (Stevens, 2009, p.148). Taraf signifikansi yang digunakan pada uji keefektifan adalah 0,05. Sedangkan uji univariat dilakukan dengan menggunakan independent sample t test dengan taraf signifikansi 0,01 . Uji ini digunakan untuk melihat apakah pendekatan realistik lebih efektif dibandingkan dengan pembelajaran konvensional.

\section{HASIL DAN PEMBAHASAN}

\section{Hasil Penelitian}

Hasil penelitian ini terdiri atas hasil uji keefektifan dan uji komparasi keefektifan antara kelompok kelompok eksperimen yang menggunakan pendekatan realistik dan kelompok kontrol yang menggunakan pembelajaran konvensional. Hasil uji keefektifan dengan menggunakan one sample t-test akan disajikan pada Tabel 2.

Tabel 2. Hasil Uji Keefektifan Pendekatan Realistik

\begin{tabular}{ccccc}
\hline Variabel & $\overline{\boldsymbol{x}}$ & Nilai Tes & $\mathbf{t}_{\text {hitung }}$ & Sig \\
\hline PB & 70,54 & 65 & 2,182 & 0,018 \\
KPMM & 25,81 & 33 & $-4,566$ & 1,000 \\
KD & 96,76 & 87 & 6,462 & 0,000 \\
\hline
\end{tabular}

Berdasarkan hasil perhitungan pada Tabel 2 terlihat bahwa untuk variabel $\mathrm{PB}$ dan $\mathrm{KD}$ memiliki taraf signifikansi lebih kecil dari 0,05. Ini berarti pendekatan realistik efektif ditinjau dari prestasi dan kepercayaan diri namun tidak efektif ditinjau dari kemampuan pemecahan masalah karena nilai $t_{\text {hitung }}$ adalah negative dan taraf signifikansinya lebih dari 0,05 . Setelah melakukan uji keefektifan, maka dilanjutkan dengan menguji perbedaan keefektifan antara pendekatan realistik dengan pembelajaran konvensional menggunakan uji multivariat $T^{2}$ Hotelling dengan bantuan SPSS 20,0 for Windows. Hasil perhitungan tersebut menunjukkan bahwa taraf signifikansi yang diperoleh $0,000<0,05$. Ini menunjukkan bahwa terdapat perbedaan keefektifan antara kelas eksperimen dengan kelas kontrol ditinjau dari prestasi belajar, kemampuan pemecahan masalah, dan kepercayaan diri siswa terhadap matematika. Karena berdasarkan hasil perhitungan tersebut menyatakan terdapat perbedaan keefektifan, maka untuk dapat menyimpulkan mana yang lebih efektif terlebih dahulu akan di uji kembali dengan menggunakan uji independent sample ttest.

Tabel 3. Hasil Independet Sample t-test

\begin{tabular}{ccc}
\hline Variabel & T & Signifikansi \\
\hline PB & 3,609 & 0,000 \\
KPMM & 4,626 & 0,000 \\
KD & 3,292 & 0,001 \\
\hline
\end{tabular}

Berdasarkan hasil perhitungan pada Tabel 3 terlihat bahwa nilai signifikansi dari masingmasing variabel terikatnya adalah lebih kecil 0,01 . Dengan demikian dapat disimpulkan bahwa pembelajaran matematika dengan pendekat- 
an realistik lebih efektif daripada pembelajaran konvensional ditinjau dari prestasi belajar, kemampuan pemecahan masalah, dan kepercayaan diri siswa terhadap matematika. Hal ini sesuai dengan hasil analisis deskriptif yang menunjukkan bahwa rata-rata pada kelas eksperimen lebih besar dari pada kelas kontrol, sehingga rata-rata tersebut memberikan kontribusi maksimal pada kelas eksperimen.

Berdasarkan hasil analisis despritif juga menunjukkan bahwa pembelajaran matematika dengan pendekatan realistik berdampak positif terhadap prestasi belajar, kemampuan pemecahan masalah, dan kepercayaan diri siswa terhadap matematika. Hal ini terlihat dari kondisi awal siswa sebelum dan sesudah diberikan perlakuan. Pada kondisi awal di kelas eksperimen tidak ada satupun siswa yang mencapai ketuntasan untuk prestasi belajar dan kemampuan pemecahan masalah. Namun untuk kepercayaan diri, baik pada kelas kontrol ataupun kelas eksperimen sudah mencapai tuntas hanya saja belum ada siswa yang mencapai kriteria sangat tinggi dan masih banyak siswa yang berada pada kriteria sedang. Sehingga perlakuan tetap harus dilakukan untuk melihat seberapa besar kemajuan yang dibuat oleh suatu pendekatan. Berikut adalah hasil analisis deskriptif dari kedua kelas.

Tabel 4. Rerata Kelas Eksperimen dan Kelas Kontrol

\begin{tabular}{ccccc}
\hline \multirow{2}{*}{ Deskripsi } & \multicolumn{2}{c}{ Realistik } & \multicolumn{2}{c}{ Konvensional } \\
\cline { 2 - 5 } & Pre & Post & Pre & Post \\
\hline PB & 35,41 & 70,54 & 38,61 & 54,17 \\
KPMM & 7,38 & 25,81 & 6,14 & 16,03 \\
KD & 84,24 & 96,76 & 86,25 & 89,92 \\
\hline
\end{tabular}

\section{Pembahasan}

Hasil uji one sample t-test menunjukkan bahwa pendekatan realistik efektif ditinjau dari prestasi belajar siswa. Hal ini sesuai dengan hasil penelitian yang dilakukan oleh Rahmawati (2009) bahwa pembelajaran realistik lebih efektif ditinjau dari ketercapaian ketuntasan belajar dan respon siswa terhadap pembelajaran matematika juga menjadi lebih positif. Hasil ini sesuai pula dengan hasil penelitian yang dilakukan oleh Yu Liang Chang \& Yu I Huang (2014) bahwa pembelajaran dengan pendekatan realistik dapat membantu siswa untuk lebih memahami dalam belajar aljabar. Apabila siswa terbantu dalam belajar aljabar, maka berdampak positif pula pada ketuntasan belajarnya pada materi aljabar.
Berdasarkan hasil analisis deskriptif, terlihat pula bahwa rerata siswa sebelum dan sesudah diberikan perlakuan mengalami peningkatan sehingga pendekatan realistik dapat membantu siswa untuk meningkatkan kemampuan pemecahan masalah siswa. Hal ini sesuai dengan penelitian yang dilakukan oleh Riandi Marisa (2011) bahwa pendekatan realistik dapat meningkatkan kemampuan pemecahan masalah matematika siswa, namun hasil ini tidak sesuai dengan analisis keefektifan dengan menggunakan uji one sample t-test. Hasil analisis menunjukkan bahwa pendekatan realistik tidak efektif ditinjau dari kemampuan pemecahan masalah matematika siswa, karena rerata kelas tidak melebihi skor yang sudah ditentukan. Hal ini dikarenakan sebagian besar siswa masih kesulitan dalam melakukan operasi hitung bilangan bulat.

Berdasarkan hasil pengamatan guru selama proses penelitian, terdapat beberapa masalah yang dihadapi oleh siswa diantaranya adalah siswa masih kesulitan ketika melakukan operasi hitung bilangan bulat, beberapa siswa masih juga mengalami kesulitan dalam memodelkan permasalahan dunia nyata ke dalam bentuk kalimat matematika. Selain itu siswa juga mengalami kesulitan ketika menentukan strategi atau cara apa yang akan digunakan untuk menyelesaikan masalah sehingga sebagian siswa memilih untuk menggunakan cara non formal yang sesuai dengan tingkat berpikir mereka apabila diberikan suatu permasalahan dalam bentuk soal latihan.

Hasil pengamatan tersebut didukung pula dengan hasil wawancara peneliti kepada guru matematika yang mengampu kedua kelas ini, bahwa sebagian siswa masih lemah dalam operasi hitung bilangan bulat seperti penjumlahan, pengurangan, pembagian dan perkalian. Materi ini merupakan titik pangkal dari matematika yang harusnya sudah dikuasai oleh siswa sejak di jenjang Sekolah Dasar (SD). Hal ini bukan tidak mungkin untuk diperbaiki namun butuh proses yang tidak sebentar dalam memberikan perlakuan pada setiap siswa sehingga siswa dapat lebih beradaptasi dengan cara belajar yang dapat membantu siswa dalam mengkonstruksi pengetahuannya.

Pembelajaran matematika dengan pendekatan realistik memfasilitasi siswa untuk mengkontruksi pengetahuan siswa sesuai dengan tahap perkembangan kognitif dari masingmasing siswa. Siswa diberikan kebebasan untuk menghasilkan jawaban sendiri (free production) 
sesuai dengan logika berpikir siswa sehingga terdapat beragam cara yang dapat dihasilkan siswa melalui proses ini. Pendekatan ini juga memberikan dampak positif terhadap siswa dalam pembelajaran matematika diantaranya adalah siswa terlihat lebih bersemangat, santun dan antusias ketika memulai pembelajaran matematika. Siswa juga berani mengemukakan pendapat dan menjawab pertanyaan guru dengan menggunakan berbagai variasi jawaban yang mereka pikirkan, baik itu cara formal ataupun cara non formal lalu mempresentasikannya di depan kelas. Berikut adalah hasil dokumentasi jawaban-jawaban siswa yang meliputi cara non formal sampai cara formal.

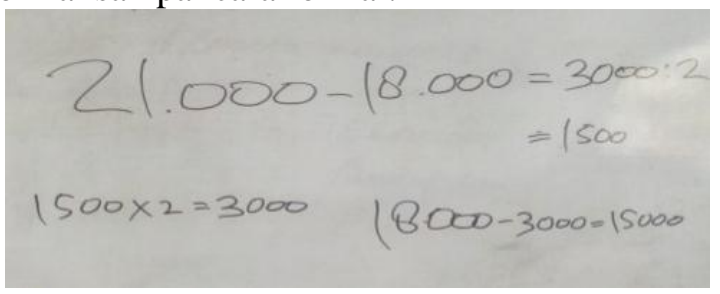

Gambar 1. Cara Nonformal

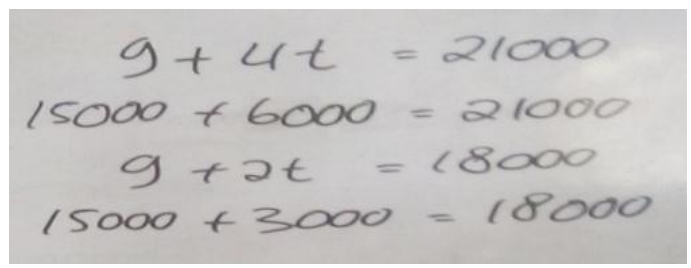

Gambar 2. Cara Semi Formal

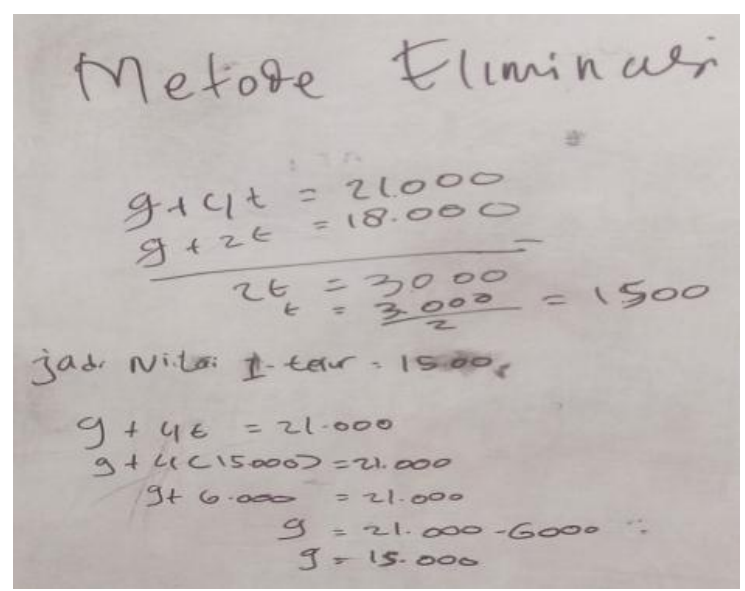

Gambar 3. Cara Formal

Hasil analisis data pretest dengan menggunakan Manova menunjukkan bahwa tidak ada perbedaan kemampuan awal siswa pada materi SPLDV antara kelas eksperimen dan kelas kontrol ditinjau dari prestasi belajar, kemampuan pemecahan masalah, dan kepercayaan diri siswa terhadap matematika. Ini berarti sebelum diberikan perlakuan pada kelas eksperimen ataupun kelas kontrol ditinjau dari ketiga variabel terikat tersebut tidak berbeda kemampuan awalnya. Sehingga kedua kelas berada pada tingkatan yang sama sebelum perlakuan. Namun setelah diberikan perlakuan, Nampak perbedaan antara kedua kelas ditinjau dari masing-masing variabel terikatnya.

Hasil analisis menunjukkan bahwa terdapat perbedaaan keefektifan antara kelas eksperimen dan kelas kontrol ditinjau dari prestasi belajar, kemampuan pemecahan masalah, dan kepercayaan diri siswa terhadap matematika. Dikarenakan terdapat perbedaan keefektifan antara kedua kelompok, maka dilakukan uji univariat independent sample t-test untuk mengetahui rerata variabel kelompok mana yang memberikan kontribusi maksimal terhadap perbedaan keefektifan antara kedua kelompok. Adapun hasil uji lanjut yang telah dilakukan dengan uji independent sample t-test dapat dilihat pada tabel 5 berikut ini.

Tabel 5. Hasil Independent Sample t-test

\begin{tabular}{ccc}
\hline Variabel & T & Signifikansi \\
\hline PB & 3,609 & 0,000 \\
KPMM & 4,626 & 0,000 \\
KD & 3,292 & 0,001 \\
\hline
\end{tabular}

Berdasarkan hasil analisis tersebut terlihat bahwa taraf signifikansi dari ketiga variabel terikatnya kurang dari 0,01 . Hal ini menunjukkan bahwa pembelajaran matematika dengan pendekatan realistik lebih efektif daripada pembelajaran konvensional ditinjau dari prestasi belajar, kemampuan pemecahan masalah, dan kepercayaan diri siswa terhadap matematika. Hasil ini didukung pula oleh hasil analisis deskriptif yang menunjukkan bahwa rerata kelompok eksperimen lebih tinggi dari kelompok kontrol ditinjau dari prestasi belajar, kemampuan pemecahan masalah, dan kepercayaan diri matematika siswa.

\section{SIMPULAN DAN SARAN}

\section{Simpulan}

Berdasarkan hasil penelitian dan pembahasan tersebut, maka dapat disimpulkan bahwa pendekatan realistik efektif ditinjau dari prestasi belajar, pendekatan realistik tidak efektif ditinjau dari kemampuan pemecahan masalah, pendekatan realsitik efektif ditinjau dari kepercayaan diri siswa terhadap matematika. Selain itu, terdapat perbedaan keefektifan antara kelas eksperimen dan kelas kontrol sehingga menyebabkan pembelajaran matematika dengan 
pendekatan realistik lebih efektif dari pembelajaran konvensional ditinjau dari prestasi belajar, kemampuan pemecahan masalah, dan kepercayaan diri siswa terhadap matematika.

\section{Saran}

Sebagai tindak lanjut dari hasil penelitian ini dapat dikemukakan beberapa saran bagi peneliti lain yang ingin melakukan penelitian dengan pendekatan matematika realistik disarankan untuk meneliti hal-hal yang berkaitan dengan materi dan aspek afektif maupun kognitif yang benar-benar menjadi masalah di sekolah atau kelas yang akan dijadikan tempat penelitian. Hal ini bertujuan agar upaya perbaikan yang dilakukan benar-benar memberikan kontribusi positif bagi siswa, guru, dan tempat sekolah tempat penelitian berlangsung.

\section{DAFTAR PUSTAKA}

Adams, D., \& Hamm, M. (2010). Demystify math, science, and technology: creativity, innovation, and problem solving. Lanham: Rowman \& Littlefield Publishing Group, Inc.

Azmandian, A. (2010). Think yourself successful: Rewire your mind become confident and achievement your goals. New York: McGraw Hill Companies, Inc.

Bell, F. H. (1978). Teaching and learning mathematics: In secondary school. Dubuque: Wm. C. Brown Company Publishers.

Burton, K., \& Platts, B. (2006). Building confidence for dummies. West Sussex: John Wiley \& Sons, Ltd.

Cai, J., et al. (2009). Effective mathematics teaching from teachers' perspectives: National and cross-national studies. Rotterdam: Sense Publisher.

Chang, Y. L., \& Huang, Y. I. (2014). A Study of improving eighth graders' learning deficiency in algebra by appling a realistic context instructional design. International Education Studies, Volume 7, No 1; 1-8.

Collins, J. W., \& O'Brien, N. P. (2003). The greenwood dictionary of education. Westport: Greenwood Press.

Fauzan, A., \& Yerizon. (2013). Pengaruh pendekatan realistik dan kemandirian belajar terhadap kemampuan matematis siswa. Tersedia pada: http://jurnal.fmipa.unila.ac.id/index.php/s emirata/article/viewFile/699/519. (11 Juli 2014)

Freudenthal, H. (1973). Mathematics as an educational task. Dodrecht: D. Reidel.

Freudenthal, H. (2002). Revisiting mathematics education: China Lectures. London: Kluwer Academic Publisher.

Goel, M., \& Aggarwal, P. (2012). A comparative study of self confidence of single child and child with sibling. International Journal of Research in Social Science, Volume 2, Issue 3, 89-98.

Gravemeijer, K. (1994). Developing realistic mathematics education. Utrecht: Freudenthal Institute.

Huberty C.J., \& Olejnik S. (2006). Applied MANOVA and discriminant analysis. New Jersey : John Wiley \& Sons, Inc.

Johnson, R. A., \& Wichern, D. W. (2007). Applied multivariate statistical analysis. New Jersey: Pearson Prentice-Hall, Inc.

Karatas, I., \& Baki, A. (2013). The effect of learning environments based on problem solving on students' achievements of problem solving. International Electronic Journal of Elementary Education, 5(3), 249-268.

Marisa, R. (2011). Pembelajaran matematika dengan pendekatan realistik untuk meningkatkan kemampuan pemecahan masalah dan disposisi matematis siswa. Tesis: Universitas Pendidikan Indonesia (UPI). Tersedia pada: http://repository.upi.edu/8038/. Agustus 2014)

McCoach, D. B., Gable, R. K., \& Madura, J. P. (2013). Instrument development in the affective domain: School and corporate applications. New York: Springer.

McElmeel, S. L. (2002). Character education. Colorado: Greenwood Publishing Group, Inc.

NCTM. (1989). Curriculum and evaluation standards for school mathematics. Virginia: NCTM, Inc.

NCTM. (2000). Principles and standards for school mathematics. Reston: NCTM, Inc. 
Nitko, A. J., \& Brookhart, S. M. (2011). Educational assessment of student. New Jersey: Pearson Education.

Noyes, A. (2007). Rethinking school mathematics. London: Paul Chapman.

OECD. (2014). PISA 2012 result: What student know can do - student performance in mathematics, reading and science (Volume I, Revised edition, February 2014), PISA, OECD Publishing. http://dx.doi.org/10.1787/9789264201118 -en.

Phye, G. D. (1997). Handbook of classroom assessment: Learning, adjustment, and achievement. California: Academic Press Inc

Polya, G. (1957). How to solve it: A new aspect of mathematical method. New Jersey: Princeton University Press.

Preston, D. L. (2001). 365 Steps to self confidence. Glasgow: How to Books Ltd.

Rahmawati. (2009). Pengembangan model pembelajaran matematika realistik (PMRI) tentang perbandingan di kelas VII SMP. Tesis: Universitas Negeri Yogyakarta (UNY).

Schunk, D. H. (2012). Learning theories: An educational perspective. New York: Pearson.
Suherman, E. et al. (2003). Strategi pembelajran matematika kontemporer. Bandung: JICA.

Srivastava, S. K. (2013). To study of academic achievement on the level of self confidence. Journal of Psychosoc, Volume 18 No 1, 41-51.

Stevens, J. (2009). Applied multivariate statistics for the social sciences. New York: Routledge.

Streefland, L. (1991). Fraction in realistic mathematics education: A paradigm of developmental research. Dodrecht: Kluwer Academic Publishers.

Van den Heuvel-Panhuizen, M. (2001). Realistic mathematics education as work in progress. Proceedings of 2001 The Netherlands and Taiwan Conference on Mathematics Education, Taipe, Taiwan, 19-23 November 2001, 1-43.

Yoder, J., \& Proctor, W. (1988). The self confident child. Virginia: Library of Congress.

Wijaya, A. (2012). Pendidikan matematika realistik: Suatu alternatif pendekatan pembelajaran matematika. Yogyakarta: Graha Ilmu. 